\title{
A novel growth stimulating activity from BRL-3A cell conditioned medium
}

\author{
S.-Q. X u, C. Sell, G. C. DuBois and R. Baserga \\ Kimmel Cancer Institute, Thomas J efferson University, Philadelphia, Pennsylvania, USA
}

(Received 25 August 1997; revision accepted 29 September 1997)

\begin{abstract}
The $\mathrm{R}^{-}$cell line is a 3T 3-like cell line originating from mouse embryos with a homozygous disruption of the type 1 insulin-like growth factor receptor (IGF-IR) genes. A Ithough $\mathrm{R}^{-}$cells cannot grow at all in serum-free medium (SFM) supplemented by several known growth factors, either singly or in combination, they are able to grow in $10 \%$ serum, albeit at a reduced rate. These findings suggested that serum contains an unknown, or unidentified, growth factor that can promote cell growth even in cells devoid of IGF-IRS. In an effort to identify such growth factor, we searched, using $\mathrm{R}^{-}$cells, for a growth and DNA synthesis stimulating activity in SFM conditioned by different cell lines. We found that the BRL-3A cell line secreted an activity capable of stimulating DNA synthesis and cell proliferation in $\mathrm{R}^{-}$cells. This activity (which is concentration-dependent) can be collected and concentrated by ultrafiltration, it is heat-labile, proteinase $\mathrm{K}$-sensitive and has a size larger than $10 \mathrm{kD}$ a. Because of the resistance of $\mathrm{R}^{-}$cells to stimulation by known growth factors, we believe that this activity is due to a novel polypeptide secreted by BRL-3A cells. Further characterization of the active component(s) is in progress.
\end{abstract}

$\mathrm{R}^{-}$cell line is a fibroblast cell line, generated, by using the same protocol to generate 3T3 cell lines, from mouse embryos homozygous for a targeted disruption of the Igflr genes (Baker et al. 1993, Liu et al. 1993), encoding the type 1 insulin-like growth factor receptor. $\mathrm{R}^{-}$cells are able to grow in $10 \%$ serum, albeit at a reduced rate in comparison to mouse embryo fibroblasts with a wild-type number of IG F-IR s (Sell et al. 1993). H owever, R- cells cannot grow at all in serum-free medium (SFM) supplemented with purified growth factors. Several known growth factors were tested singly or in association with other growth factors, and all failed to support the growth of $\mathrm{R}^{-}$cells. They include the following growth factors: PDGF, EGF, IFG-I, IGF-II, insulin, b-FGF, a-FGF, TGF- $\alpha$, TGF- $\beta$ and HGF (Sell et al. 1994). With the exception of TGF- $\beta$, all these growth factors (singly or in appropriate combinations) support the growth of $\mathrm{W}$-cells (a fibroblast cell line generated from mouse embryos littermates to the embryos with deleted I gf1r genes), or other 3T 3-like cell lines. $\mathrm{R}^{-}$ cells are also refractory to transformation by SV 40 large T antigen (Sell et al. 1993), and/or an activated and overexpressed Ras (Sell et al. 1994), by the bovine papillomavirus E5 oncoprotein (Morrione, DeAngelis \& Baserga 1995), the human papillomavirus 16 E 7 (Steller et al. 1996) and an activated C-src (Valentinis et al. 1997) and by over-expressed growth factor receptors, such as the EGF-R (Coppola et al. 1994), the PDGF- $\beta$ receptor Street, 624 BLSB, Philadelphia, Pennsylvania 19107, U SA. 
(D eA ngelis, F erber \& Baserga 1995) and the insulin receptor (M iura et al. 1995, M orrione et al. 1997). All these conditions readily transform 3T3 cells and other mouse embryo fibroblasts with endogenous IGF-IRS. R e-introduction into $R^{-}$cells of a plasmid expressing a human IGF-IR CDNA restores growth in SFM supplemented by growth factors and the susceptibility to transformation.

IGF-I is the second growth factor for many cell types (reviewed by Baserga et al. 1997a), and, in fact, $\mathrm{R}^{-}$cells overexpressing either the EGF-R (Coppola et al. 1994) or the PDGF- $\beta$ receptor (DeA ngelis et al. 1995) cannot even grow in SF M supplemented either by epidermal growth factor (EGF) or platelet-derived growth factor (PDGF), indicating that the presence of a functional IGF-IR is required for the stimulation by other growth factors. These special features make $\mathrm{R}^{-}$cells a unique cell line for the testing and isolation of novel growth factors which stimulate cell growth through pathways that are not shared with the known growth factor receptors, including the IGF-IR. The ability of $\mathrm{R}^{-}$cells to grow in $10 \%$ serum, but not in SFM supplemented by known growth factors, does indeed suggest that they are stimulated by a not yet identified growth factor; however, since serum is a very complex mixture of stimulatory and inhibitory factors, we hoped that the use of conditioned media may facilitate the search for novel growth factors.

$\mathrm{U}$ sing $\mathrm{R}^{-}$cells to screen for growth and DNA synthesis stimulating activity in medium conditioned by six cell lines, WI-38, BALB/C 3T3, M CF-7, BRL-7, BRL-3A, T98G and $\mathrm{T} 24 \mathrm{H}$, we found that the last three cell lines could secrete an activity that stimulated the growth of $\mathrm{R}^{-}$cells. We report here our preliminary data on the characterization of this activity from the CM of $B R L-3 A$ cells. It is heat-labile, proteinase $K$ sensitive, has a size larger than $10 \mathrm{kDa}$ and the stimulation is concentration-dependent. These results indicate that the CM of BRL-3A cells contains a polypeptide that has growth stimulatory activity on $\mathrm{R}^{-}$cells, and therefore is not one of the better known growth factors. While its purification is in progress, we would like to present here its biological characterization.

\section{MATERIALSAND METHODS}

\section{Cell lines and culture conditions}

$\mathrm{R}^{-}$cells

A Il experiments used as the test cell line, $\mathrm{R}^{-}$cells (Sell et al. 1993, 1994), which are 3T 3-like cells derived from mouse embryos with a targeted disruption of the IG F-IR genes (Baker et al. 1993, Liu et al. 1993). These cells have been repeatedly described and characterized in previous papers from this laboratory (Coppola et al. 1994, M iura et al. 1995, Rubini et al. 1997). They grow in $10 \%$ fetal bovine serum (FBS), but they do not grow at all in SFM supplemented with purified growth factors.

For the production of conditioned medium (CM), the following cell lines were used: WI-38, BA LB/C 3T 3, M CF-7, BRL-3A, T98G and T24H. WI-38 is a human lung diploid cell line derived by $L$. H ayflick from normal embryonic ( 3 months gestation) lung tissue (Hayflick 1965). BA LB /C 3T 3 have been grown in our laboratory for several years. M CF-7 is a human breast adenocarcinoma cell line derived from a pleural effusion (Soule et al. 1973). BR L-3A is a cell line originated as a clone from a 5-week-old female Buffalo rat liver ( $B R L$ ). Serumfree medium conditioned by the BRL-3A cells produces a family of polypeptides termed multiplication-stimulating activity or M SA which have been reported to be related to somatomedins and stimulate $\left[{ }^{3} \mathrm{H}\right.$ ]-thymidine incorporation into DNA in chick embryo fibroblasts and human skin fibroblasts (Dulak \& Temin 1973a, b, Dulak \& Shing 1977, Nissley et al. 1977). T98G is human glioblastoma cell line derived from a glioblastoma multiforme tumour from 
a 61-year-old male (Stein 1979). T24H, is an NIH/3T3 cell line transfected with T24 oncogene carrying a point mutation at codon 12 of $\mathrm{H}$-ras oncogene (Srivastava et al. 1985). All these cell lines were maintained routinely in DMEM medium containing $10 \%$ fetal bovine serum except for $B R L-3 A$, which is maintained in F-10 medium plus $10 \%$ fetal bovine serum.

\section{Preparation of conditioned medium}

$B R L-3 A$ cells $\left(1 \times 10^{6}\right)$ were plated in $10-\mathrm{cm}$ petri dishes in $10 \mathrm{ml}$ of $\mathrm{F}-10$ medium containing $10 \% \mathrm{FBS}$ and were incubated at $37^{\circ} \mathrm{C}$ in a humidified $\mathrm{CO}_{2}$ incubator. A fter reaching subconfluence, the cells were washed with three times $\mathrm{H}$ ank's solution, then incubated in $10 \mathrm{ml}$ of SFM. The following day this medium was discarded, and the cells were washed with Hank's solution, again three times, then fresh SFM was added. The medium from these cultures was repeatedly collected and pooled, unless otherwise noted. Conditioned medium from cultures of BRL-3A cells was harvested for a period of 1 month, after which the cultures were discarded and replaced by new cultures. Collected medium was sterilized using $0.2 \mu \mathrm{m}$ filter and stored frozen at $-20^{\circ} \mathrm{C}$ until needed. In the primary screening of other cell lines for the identification of stimulating activity in the $\mathrm{CM}$, the same procedure was followed.

\section{Determination of cell growth}

For all experiments on stimulation of cell proliferation, the cells were seeded at a density of $5 \times 10^{3} / \mathrm{cm}^{2}$ in medium containing $10 \%$ FBS and allowed to attach for $24 \mathrm{~h}$. After washing three times with $\mathrm{H}$ ank's solution, the cultures were placed in serum-free DMEM medium (SFM), and then treated as described in the respective experiments (see R esults). The cell numbers were at time 0 and after 3 days in culture. For Figure 1 only, the SFM was also supplemented with $0.1 \%$ bovine serum albumin, and $50 \mu \mathrm{g} / \mathrm{ml}$ transferrin.

\section{DNA synthesis}

$\mathrm{R}^{-}$cells were seeded at a density of $5 \times 10^{3} / \mathrm{cm}^{2}$ on coverslips in DMEM medium containing $10 \% \mathrm{FBS}$ and allowed to attach for $24 \mathrm{~h}$. The cultures were then made quiescent for $96 \mathrm{~h}$ in SFM prior to the addition of growth factors or CM. Tritiated thymidine $(0.5 \mu \mathrm{Ci} / \mathrm{ml})$ was added at the same time as growth factors or $\mathrm{CM}$, and the incubations were continued for $24 \mathrm{~h}$. The cells were then fixed in cold methanol and autoradiographed by standard procedures. The percentage of labelled cells was determined by scoring a total of 1000 cells. DNA synthesis stimulating activity was expressed in percentage of labelled nuclei.

\section{Ultrafiltration and protein assay}

Y M 10 membrane disks (A micon) were used to concentrate and separate the BRL-3A cell conditioned medium into two different fraction sizes, i.e. smaller than $10 \mathrm{kD}$ a and larger than $10 \mathrm{kD}$ a. Protein concentrations of all samples were determined by Bio-R ad protein assay (Bio-R ad Laboratories, Hercules, CA) using BSA as the standard.

\section{Biochemical characterization of $\mathrm{CM}$}

To observe the effect of heat on the growth stimulating activity of $B R L-3 A C M, 2 \mathrm{ml}$ each of the original $B R L-3 A C M$ were pre-heated for $30 \mathrm{~min}$ at $65^{\circ} \mathrm{C}, 85^{\circ} \mathrm{C}$, and $100^{\circ} \mathrm{C}$, respectively, then used to treat the quiescent $\mathrm{R}^{-}$cells at the same time as addition of unheated $\mathrm{CM}$ or $10 \%$ FBS or SFM only. To test the effect of proteinase $\mathrm{K}$ on this activity, $1 \mathrm{ml}$ each of BRL-3A CM was pre-incubated at $37^{\circ} \mathrm{C}$ for 20 min either with or without $100 \mu \mathrm{l}$ of proteinase $K$ beads (PK B, $1 \mathrm{mg} / \mathrm{ml}$, Sigma Chemical Company, St. Louis, M O), which were 
then removed from the CM after the pre-incubation, then mixed with SF $M$, at a ratio of $1: 1$, and used to treat the quiescent $\mathrm{R}^{-}$cells at the same time as addition of $10 \% \mathrm{FBS}$ or SFM only. Phenylmethylsulfonyl fluoride (PMSF, Sigma), a proteinase inhibitor, was used at a final concentration of $20 \mu \mathrm{m}$ to monitor the specific effect of proteinase $\mathrm{K}$ on $\mathrm{CM}$.

\section{RESU LTS}

\section{Screening of conditioned medium from different cell lines for growth stimulating activity on $\mathbf{R}^{-}$cells}

To identify this putative novel growth factor, we screened six cell lines for their ability to secrete in the conditioned medium a growth stimulating activity (Figure 1 ). $\mathrm{R}^{-}$cells were plated and made quiescent as described in $M$ aterials and $M$ ethods. The cells were left in SFM , or were supplemented with either $10 \% \mathrm{FBS}$, or PDGF $(5 \mathrm{ng} / \mathrm{ml})$ and EGF $(20 \mathrm{ng} / \mathrm{ml})$ $(P+E)$, or with conditioned medium added at a ratio of $1: 1$, from cell lines $W I-38, B A L B / C$ 3T 3, M CF-7, BRL-3A, T98G and T24H (see M aterials and M ethods for the description of these cell lines and the production of conditioned medium). When compared to SFM, the conditioned media from cell lines BRL-3A, T98G and T24H were found to stimulate the growth of $\mathrm{R}^{-}$cells substantially, the effect being close to that of $10 \% \mathrm{FBS}$, while the conditioned media from other three cell lines, WI-38, BALB/C 3T 3, and M CF-7, were found

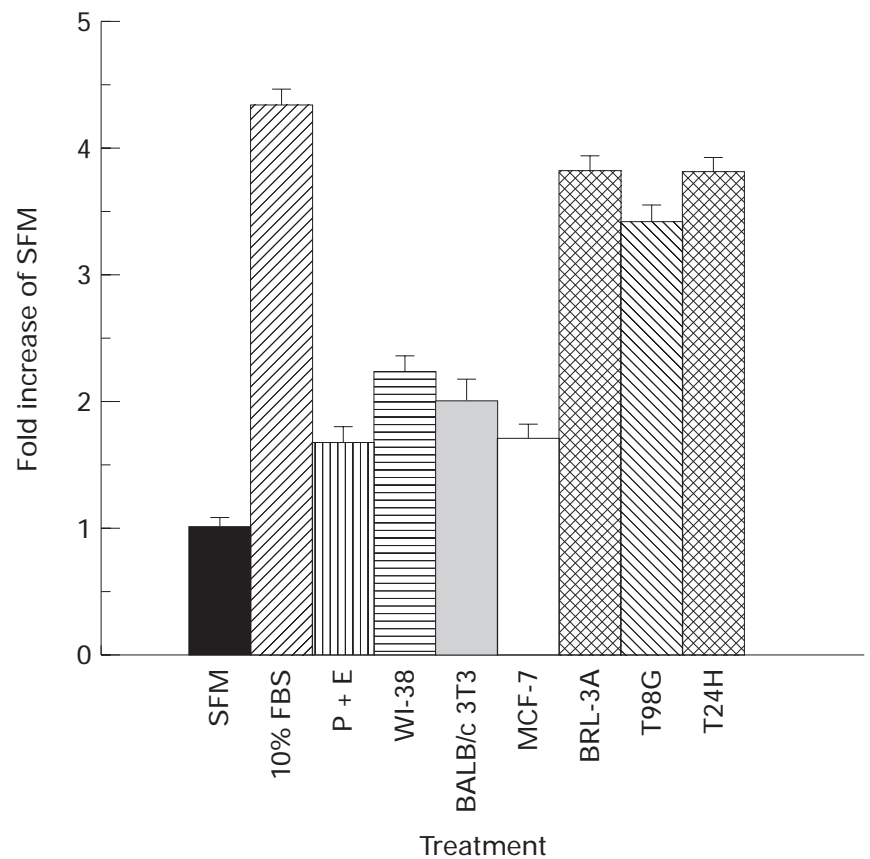

Figure 1. Screening of conditioned medium from different cell lines for growth stimulating activity on $\mathrm{R}^{-}$cells. $\mathrm{R}^{-}$cells were plated in triplicate and treated as described in $\mathrm{M}$ aterials and $\mathrm{M}$ ethods. Cell counting was done on triplicate cultures after $72 \mathrm{~h}$ incubation at $37^{\circ} \mathrm{C}$. The ordinate gives the fold increase in cell number compared to $S F M=1.0$. The source of conditioned media is indicated here and in the text. Also shown are the effect of $10 \% \mathrm{FBS}$, or a combination of PDGF ( $5 \mathrm{ng} / \mathrm{ml})$ and $E \mathrm{GF}$ $(20 \mathrm{ng} / \mathrm{ml})(P+E)$ (see $M$ aterials and $M$ ethods). Bars are given for means with standard deviations. 
to have much less growth-stimulating activity on $R^{-}$cells. The BRL-3A cell line has been previously used for the characterization of other novel growth factors (Dulak \& Temin 1973a, b, Dulak \& Shing 1977, Nissley et al. 1977, Straus, Coppock \& Pang 1981), and we therefore chose the conditioned medium of this cell line to investigate the growth stimulating activity on $\mathrm{R}^{-}$cells.

\section{Growth stimulation of diluted BR L-3A-CM on $\mathbf{R}^{-}$cells}

We carried out preliminary experiments to determine the concentration-dependence of the growth stimulating activity. A s Figure 2 shows, the stimulation of $\mathrm{R}^{-}$cells to grow (here after $72 \mathrm{~h}$ incubation at $37^{\circ} \mathrm{C}$ ) increased with increasing concentrations of BRL-3A CM. The same experiment was repeated by measuring, instead of cell number, the fraction of cells entering DNA synthesis, as measured by autoradiography with $\left[{ }^{3} \mathrm{H}\right]$-thymidine. The results (not shown) confirmed the concentration dependence of the stimulating activity in the $C M$, suggesting that some factor(s) exist in the BRL-3A CM which enable the $\mathrm{R}^{-}$cells to enter $\mathrm{S}$ phase and eventually to divide.

\section{Growth or DNA synthesis stimulation of BRL -3A-CM on $\mathbf{R}^{-}$cells is reproducible}

To confirm the preliminary data described above, several independent experiments were carried out for both growth promotion and DNA synthesis stimulation of $\mathrm{R}^{-}$cells by the $B R L-3 A-C M$ (Figures $3 \& 4$ ). In Figure 3, we determined the increase in cell number of $R^{-}$ cells, stimulated with either $10 \%$ FBS or CM from BRL-3A cells. In six independent experi-

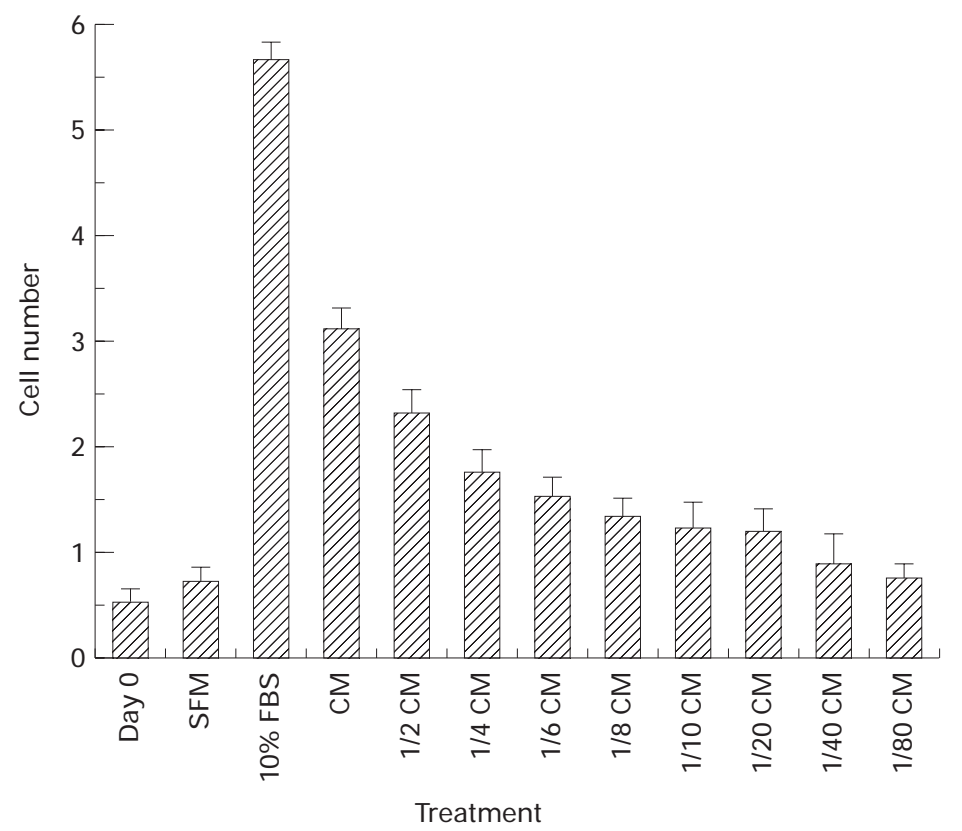

Figure 2. $G$ rowth stimulation of $R^{-}$cells by diluted $B R L-3 A$ conditioned medium (CM ). $R^{-}$cells were prepared as described in $M$ aterials and $M$ ethods and Figure 1 , and then incubated in SFM supplemented with either $10 \%$ FBS or decreasing concentrations of CM from BRL-3A cells. The abscissa gives the ratios of $\mathrm{CM}$ to SFM. Cell counting was done on triplicate cultures at time 0 and after $72 \mathrm{~h}$ incubation at $37^{\circ} \mathrm{C}$. The ordinate gives the cell number $\times 10^{4}$ per $\mathrm{cm}^{2}$. 
ments the CM stimulated the proliferation of $\mathrm{R}^{-}$cells, albeit always at a lower level than serum. In Figure 4, DNA synthesis, rather than cell number, was measured, using $\left[{ }^{3} \mathrm{H}\right.$ ]-thymidine autoradiography (see $\mathrm{M}$ aterials and $\mathrm{M}$ ethods). In seven separate experiments, the CM from BRL-3A cells was found to stimulate DNA synthesis in R ${ }^{-}$cells. Indeed, the level of stimulation is almost the same as that of $10 \% \mathrm{FBS}$, indicating that the growth stimulatory activity in the $C M$ is more effective in inducing DNA synthesis than cell division (see Discussion). These findings also show that the growth or DNA synthesis stimulating activity of BRL-3A-CM on $R^{-}$cells is reproducible. Because DNA synthesis seems to be a more sensitive indicator of $C M$ activity than cell growth, in subsequent experiments with the CM of BRL-3A cells, we used DNA synthesis as the regular assay for growth stimulating activity.

\section{The stimulating activity is repeatedly secreted into the conditioned medium}

In order to collect large amounts of CM for subsequent studies, we asked whether the growth stimulating activity could be collected repeatedly from the same plate of BRL-3A cells. $D$ ifferent rounds of collection of BR L-3A conditioned medium, designated as CM r-1, 2, 3, 6, 7, 8 in Figure 5, were tested for their ability to stimulate DNA synthesis in $R^{-}$cells. E ven the eighth round ( $\mathrm{CM} \mathrm{r-8)}$ of collection of $\mathrm{CM}$ from the same plates of $B R L-3 A$ cells could stimulate DNA synthesis in $\mathrm{R}^{-}$cells, although a slight decrease in activity could be perceived after repeated harvesting from the same plate.

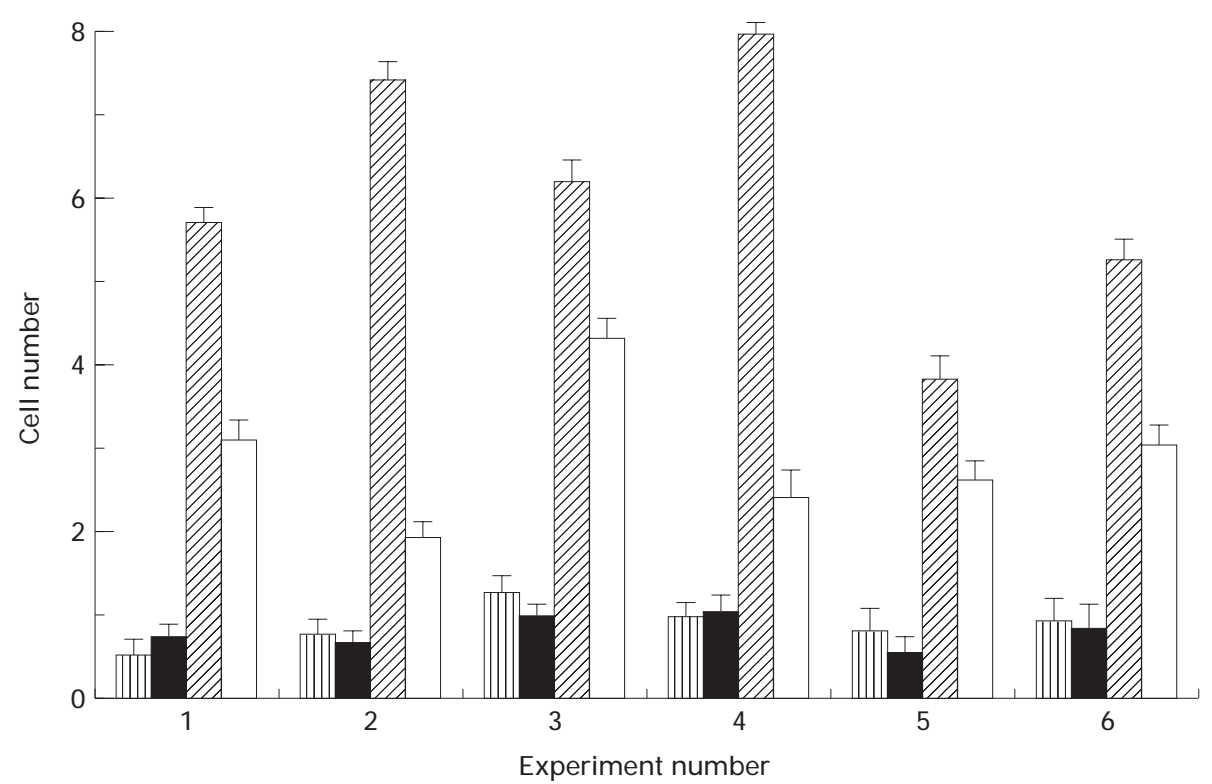

Figure 3. Growth stimulation of $R^{-}$cells by $B R L-3 A-C M$ is reproducible. $R^{-}$cells were plated in triplicate at a density of $5 \times 10^{3} / \mathrm{cm}^{2}$ overnight at $37^{\circ} \mathrm{C}$, then washed with $\mathrm{H}$ ank's solution three times, and treated as indicated below. Cell counting was done on triplicate cultures at time 0 (horizontally striped bar) and after $72 \mathrm{~h}$ incubation at $37^{\circ} \mathrm{C}$ with SFM (closed bar), $10 \% \mathrm{FBS}$ (striped bar), or $B R L-3 A$ conditioned medium (open bar). The ordinate gives the cell number $\times 10^{4}$ per $\mathrm{cm}^{2}$. Data from six independent experiments are given. 


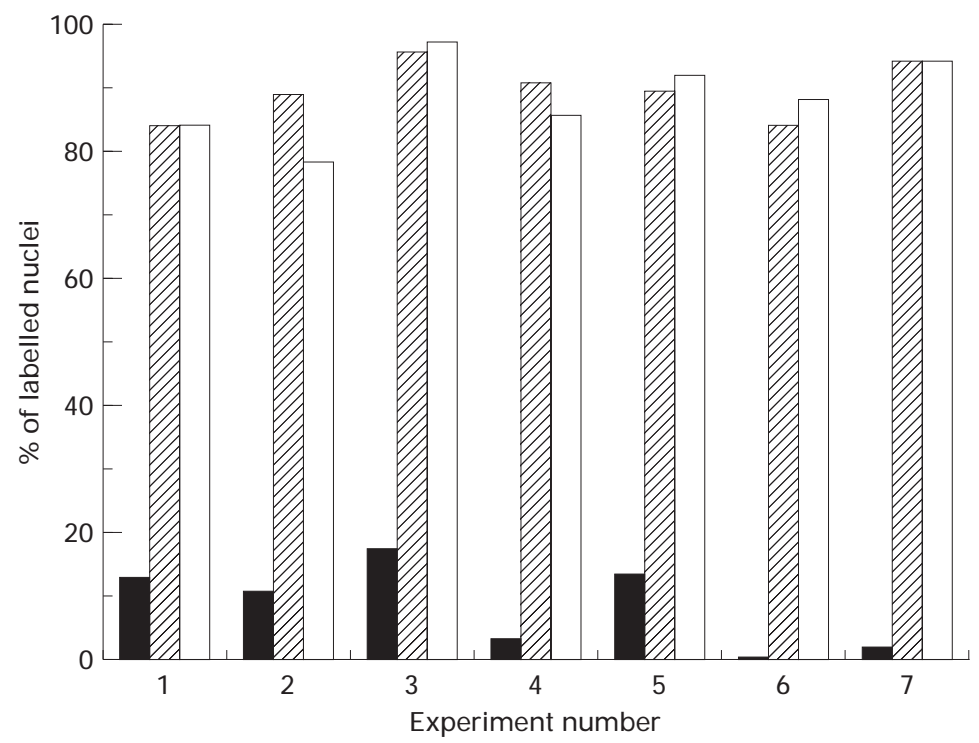

Figure 4. Stimulation of $D N A$ synthesis by $B R L-3 A-C M$ of $R^{-}$cells. $R^{-}$cells were plated and made quiescent as described in $M$ aterials and $M$ ethods. They were then left unstimulated (SFM, closed bar) or treated with either $10 \%$ FBS (striped bar) or BRL-3A conditioned medium (open bar). The percentage of nuclei labelled by $\left[{ }^{3} \mathrm{H}\right]$-thymidine in a $24-\mathrm{h}$ period is shown on the ordinate. Data from seven independent experiments are given.

\section{Growth and DNA synthesis stimulating activity is larger than $10 \mathrm{kDa}$}

U Itrafiltration through the YM 10 membrane disks were initially used to separate the CM into two fractions, i.e. larger than $10 \mathrm{kDa}$ and smaller than $10 \mathrm{kDa}$. The $\mathrm{CM}$ was also concentrated about 30 times during this procedure. When tested for activity, the volumes of the fraction were adjusted so that their effects could be compared on the same activity/ volume basis. In three independent experiments, the stimulating activity was found in the fraction larger than $10 \mathrm{kDa}$, albeit the stimulation was lower than that observed for the original CM or for $10 \%$ FBS (Figure 6a). The fraction smaller than $10 \mathrm{kDa}$ was found to have negligible growth promoting effect on $\mathrm{R}^{-}$cells (Figure 6a). A gain, the differences were clearer when the fractions were tested for their ability to stimulate DNA synthesis (Figure 6b). In fact, in this assay, the fraction larger than $10 \mathrm{kD}$ a was as active as $10 \% \mathrm{FBS}$ in stimulating DNA synthesis, while the fraction lower than $10 \mathrm{kDa}$ was essentially inactive. In addition, a series of concentrations $(0,0.25,0.5,1.25,2.5,5.0,7.5$ and $10 \mu \mathrm{g} / \mathrm{ml})$ of partially purified protein from the fraction larger than $10 \mathrm{kD}$ a were tested for their ability to stimulate DNA synthesis in $\mathrm{R}^{-}$cells. The results (Figure 7 ), clearly show a concentration dependent activity in this fraction, consistent with the data shown in Figure 2 for the unfractionated $C M$. Therefore, the growth and DNA synthesis stimulating activity in BR L-3A CM is larger than $10 \mathrm{kD}$ a.

\section{The DNA synthesis stimulating activity is heat-labile and proteinase $\mathrm{K}$-sensitive}

To test other characteristics of the $C M$ activity, $R^{-}$cells were made quiescent, and then treated with either $10 \% \mathrm{FBS}$, or $\mathrm{BRL}-3 \mathrm{~A} \mathrm{CM}$, or $\mathrm{CM}$ pre-heated at $65^{\circ} \mathrm{C}, 85^{\circ} \mathrm{C}$, and $100^{\circ} \mathrm{C}$ for $30 \mathrm{~min}$, or left unstimulated (SFM). The results shown in Figure 8, panel a, indicate that 
the D NA synthesis stimulating activity is heat-sensitive. This activity can also be abrogated by proteinase $K$ and the effect could be counteracted by addition of a proteinase $K$ inhibitor (Figure $8 \mathrm{~b}$ ). The results from these experiments suggest that the DNA synthesis stimulating activity in BRL-3A CM is associated with a polypeptide larger than $10 \mathrm{kDa}$.

\section{DISCUSSION}

$R^{-}$cells are fibroblasts generated from mouse embryos with a targeted disruption of the IGF-IR genes (Baker et al. 1993, Liu et al. 1993) by the same protocol used to generate 3T3 cells. They have been extensively characterized in previous publications: (1) they grow in $10 \%$ serum, albeit at a reduced rate (Sell et al. 1993); (2) they do not grow in SFM supplemented by purified growth factors (Sell et al. 1993, 1994); and (3) they are refractory to transformation by a variety of cellular and viral oncogenes (Sell et al. 1993, 1994, Coppola et al. 1994, D eA ngelis et al. 1995, M orrione et al. 1995, M iura et al. 1995, Steller et al. 1996, V alentinis et al. 1994, 1997), that readily transform other 3 T 3 cell lines. The growth deficits of $R^{-}$cells are promptly corrected by the stable transfection of a plasmid expressing the human IG F -IR CDNA.

The fact that $\mathrm{R}^{-}$cells are totally unresponsive to known, available growth factors, and yet grow in $10 \%$ FBS, suggests that serum must contain another growth factor, which has not yet been identified, and that can stimulate the growth of cells devoid of IGF-IR s. Identification

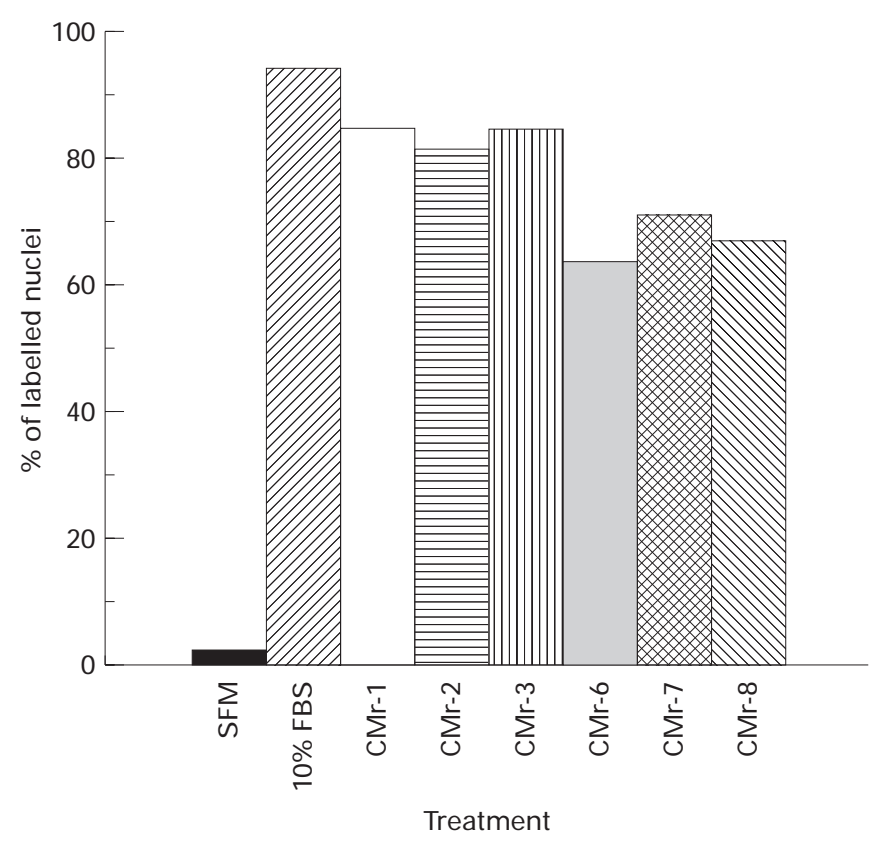

Figure 5. The DNA synthesis stimulating activity of CM from BRL-3A cells can be repeatedly collected. $\mathrm{R}^{-}$cells were plated and made quiescent as described in $\mathrm{M}$ aterials and $\mathrm{M}$ ethods. They were then treated with either $10 \% \mathrm{FBS}$, or CM from different rounds of collection from the same plates of BR L-3A cells. CM r-1, 2, 3, 6, 7, 8, represents consecutive rounds of collection. The percentage of nuclei labelled by $\left[{ }^{3} \mathrm{H}\right]$-thymidine in a $24-\mathrm{h}$ period is shown on the ordinate. Control cells were left unstimulated in SFM. 

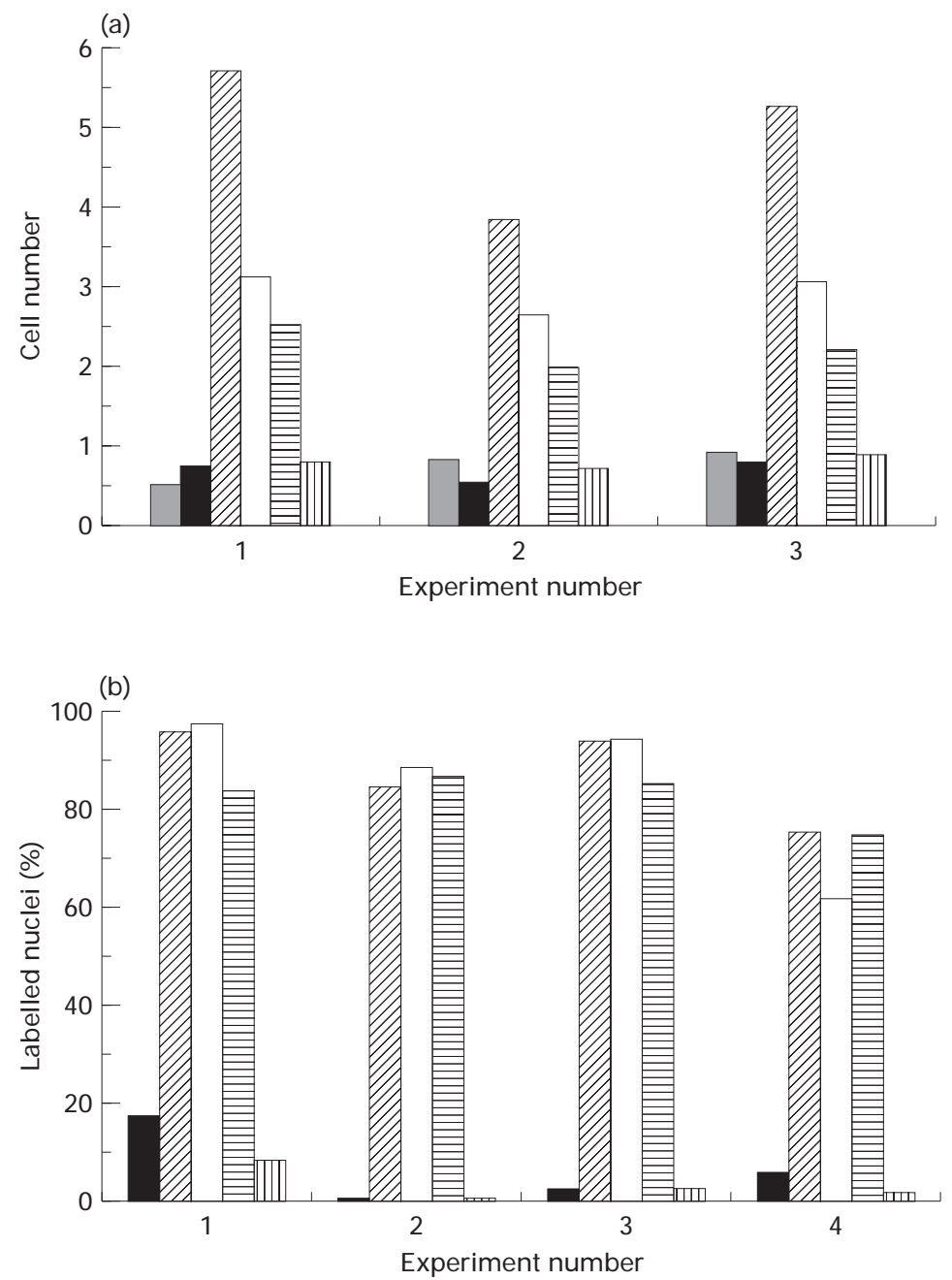

Figure 6. The growth and DNA synthesis stimulating activity is larger than $10 \mathrm{kDa}$. (a) $\mathrm{R}^{-}$cells were plated in triplicate at a density of $5 \times 10^{3} / \mathrm{cm}^{2}$ overnight at $37^{\circ} \mathrm{C}$, and treated as usual. Bars: day 0 (dotted bar), SFM (closed bar), 10\% FBS (striped bar), BRL-3A conditioned medium (open bar), fraction larger than $10 \mathrm{kDa}$ (horizontally striped bar), fraction smaller than $10 \mathrm{kDa}$ (vertically striped bar). See $M$ aterials and $M$ ethods for the fraction of $C M$. Cell counting was done on triplicate cultures at time 0 and after $72 \mathrm{~h}$ incubation at $37^{\circ} \mathrm{C}$. The ordinate gives the cell number expressed in $\times 10^{4} / \mathrm{cm}^{2}$. $\mathrm{D}$ ata from three independent experiments are given. (b) $\mathrm{R}^{-}$cells were plated and made quiescent as described in $\mathrm{M}$ aterials and $\mathrm{M}$ ethods and in (a). The percentage of nuclei labelled by $\left[{ }^{3} \mathrm{H}\right]$-thymidine in a 24-h period is shown on the ordinate. Bars: SFM (closed bars), 10\% FBS (striped bar), BRL-3A conditioned medium (open bar), fraction larger than $10 \mathrm{kDa}$ (horizontally striped bar), fraction smaller than $10 \mathrm{kD}$ a (vertically striped bar). Data from four independent experiments are shown. 


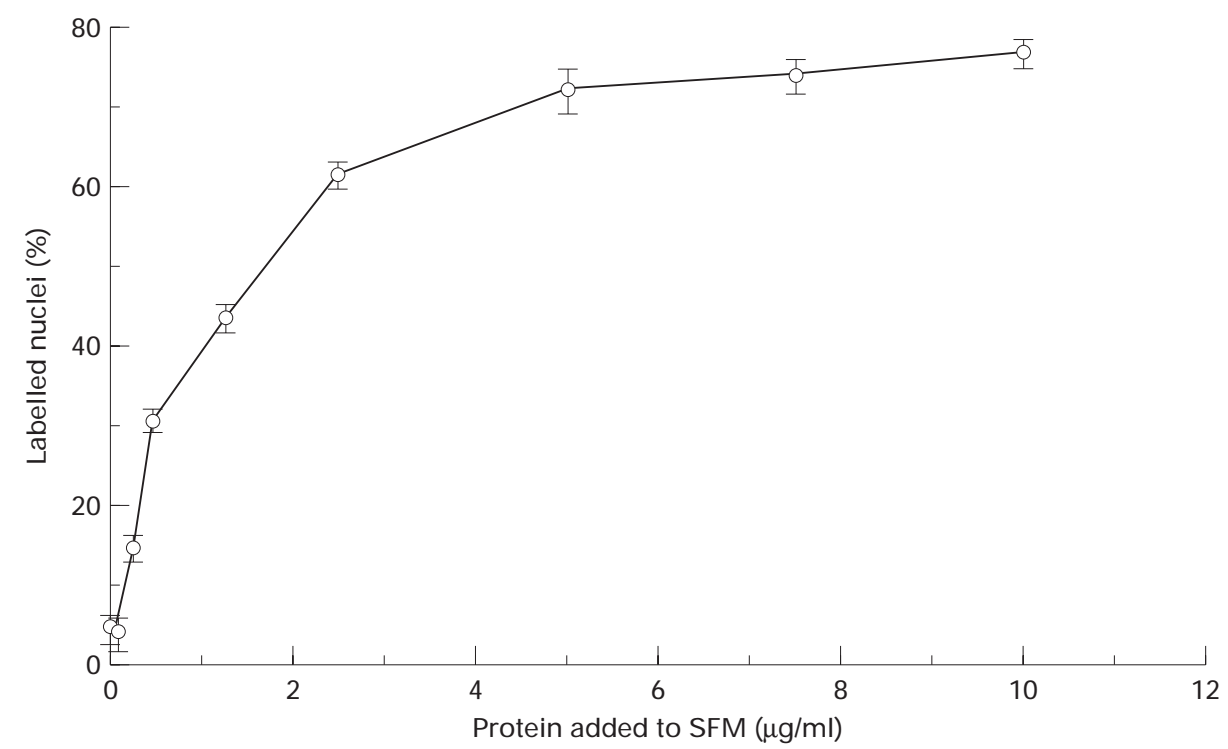

Figure 7. DNA synthesis stimulating activity is concentration-dependent. $\mathrm{R}^{-}$cells were plated and made quiescent as described in $M$ aterials and $M$ ethods. They were then treated with different concentrations $(0,0.25,0.5,1.25,2.5,5.0,7.5$ and $10 \mu \mathrm{g} / \mathrm{ml})$ of partially purified proteins from the fraction of the CM larger than $10 \mathrm{kDa}$. The percentage of nuclei labelled by $\left[{ }^{3} \mathrm{H}\right]$-thymidine in triplicate cultures in a $24-\mathrm{h}$ period is shown on the ordinate.

of growth factors in serum are notoriously difficult, and we thought that we could circumvent this problem by identifying a similar activity in the CM of certain cell lines. A lthough even this approach has also proved to be laborious, we would like to present here our data indicating that: (1) a growth stimulating activity for $\mathrm{R}^{-}$cells can be identified in the CM of some, but not all, cell lines; and (2) a partial characterization of this activity indicates that it has the properties of a polypeptide larger than $10 \mathrm{kDa}$. This statement is supported by the finding that the activity is heat-labile, proteinase $\mathrm{K}$-sensitive and can be fractionated by size.

This activity, for which we propose the temporary name of $B R L-3 A$ growth factor (BRL-GF), induces DNA synthesis more efficiently than cell growth. This is not unusual, and there are many reports in the literature indicating that certain stimuli can induce DNA synthesis without stimulating cell division, or with a much lower induction of cell division (DeA ngelis et al. 1995, Valentinis et al. 1994, for a review Baserga 1985). In fact, many purified growth factors are as good as 10\% serum in stimulating DNA synthesis, but rarely match serum (even in combination) in stimulating cell division. We have not tested BRL-GF for transformation, because colony formation in soft agar requires already $10 \%$ serum, even when the cells are completely transformed.

When BRL-3A cells are grown on a separate coverslip in the same dish as $\mathrm{R}^{-}$cells, they can stimulate DNA synthesis in the latter cells (Valentinis et al. 1997), indicating that BRL-GF is secreted in substantial amounts and is a powerful growth factor. It has been further purified through various columns, and it probably is related to a molecule of about $75 \mathrm{kD}$ a (unpublished data from our laboratory), but the last steps of purification have proved to be very difficult. However, it is not one of the known growth factors, for the reasons given 
(a)

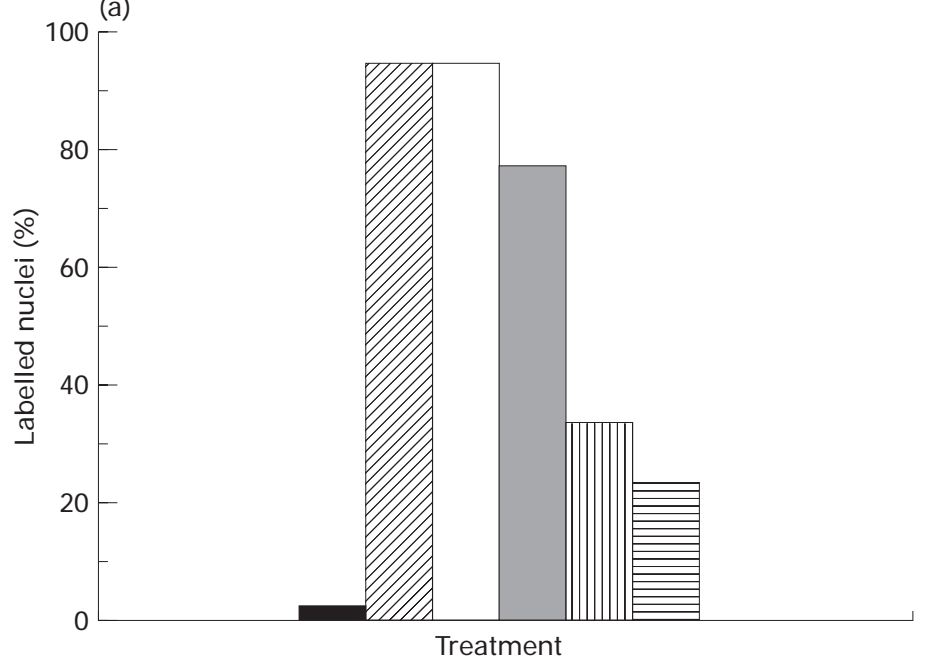

(b)

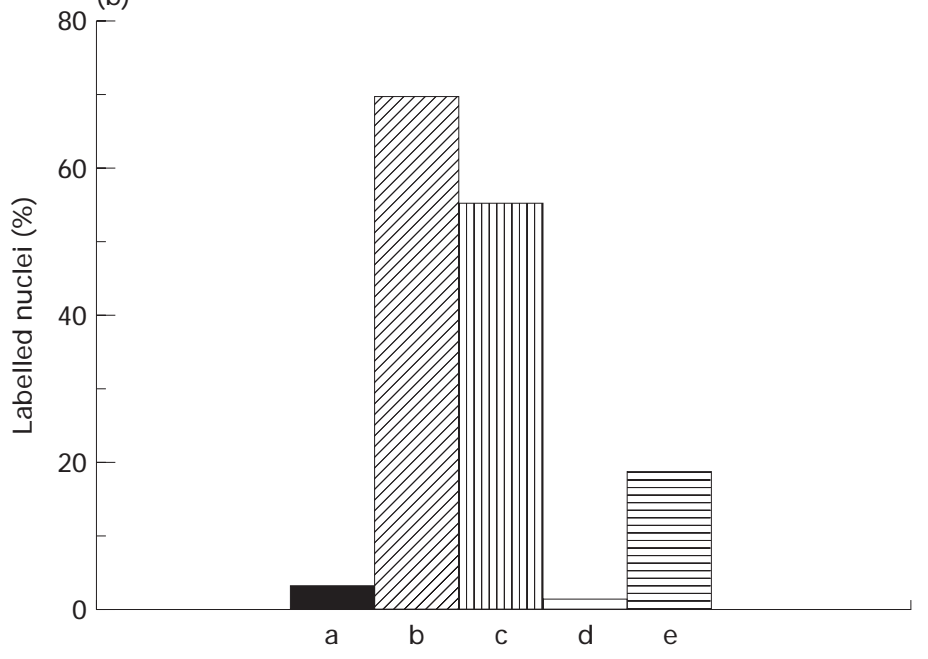

Figure 8. The DNA synthesis stimulating activity is heat labile and protease sensitive. (a) $R^{-}$cells were plated and made quiescent as described in M aterials and $M$ ethods. They were then treated with $10 \%$ FBS (striped bar), BRL-3A conditioned medium (CM, open bar), CM pre-heated for 30 min at $65^{\circ} \mathrm{C}$ (dotted bar), $85^{\circ} \mathrm{C}$ (vertically striped bar), and $100^{\circ} \mathrm{C}$ (horizontally striped bar), respectively, or left unstimulated (SFM, closed bar). The percentage of nuclei labelled by $\left[{ }^{3} \mathrm{H}\right.$ ]-thymidine in a $24-\mathrm{h}$ period is shown on the ordinate. (b) $\mathrm{R}^{-}$cells were plated and made quiescent as described in $M$ aterials and Methods. SFM (a) and 10\% FBS (b) were included as controls. One ml of BRL-3A conditioned medium was pre-incubated at $37^{\circ} \mathrm{C}$ for $20 \mathrm{~min}$ without (c) or with (d) $100 \mu \mathrm{l}$ of proteinase $\mathrm{K}$ beads (PKB, $1 \mathrm{mg} / \mathrm{ml}$ ) before mixing with $1 \mathrm{ml}$ of SFM and adding to the quiescent $\mathrm{R}^{-}$cells. PKB was also used to treat the CM along with PMSF $(20 \mu \mathrm{M})$ (e) to monitor its specific effect. The mean percentage of nuclei labelled by $\left[{ }^{3} \mathrm{H}\right]$-thymidine in duplicate in a $24-h$ period is shown on the ordinate. 
above, and also because of its probable size. A gain because of its probable size, we have directly tested the effect of hepatocyte growth factor (HGF) on $\mathrm{R}^{-}$cells, but the results indicated that the HGF was unable to stimulate DNA synthesis in $\mathrm{R}^{-}$cells and an anti-HGF antibody could not neutralize the DNA synthesis stimulating activity of partially purified protein from the BRL-3A CM (not shown).

D espite the preliminary nature of this report, we thought that it should be made known, because it makes two important points: (1) CM from BRL-3A cells (and serum) contains a polypeptide that does not have the characteristics of known growth factors, and is therefore in all probability a novel growth factor; and (2) because IG F-I is a required growth factor for many cell types in defined media (Baserga et al. 1997), $R^{-}$cells constitute a valuable resource in the search of growth factors that bypass the requirement for IG F-I.

\section{A CKNOWLEDGEMENTS}

This work was supported by grant CA 53424 from the $\mathrm{N}$ ational Institutes of $\mathrm{H}$ ealth.

\section{REFERENCES}

Baker J, Liu JP, Robertson Ej, Efstratiadis A. (1993) Role of insulin-like growth factors in embryonic and postnatal growth. Cell 75, 73.

Baserga R, Resnicoff M, D'Ambrosio C, Valentinis B. (1997a) The role of IGF-I receptor in apoptosis. Vitam. Horm. 53, 65.

BASERGa R, HONGo A, RUBINI M et al. (1997b) The IGF-I receptor in cell growth, transformation and apoptosis. Biochim. Biophys. Acta 1332, F105.

Baserga R. (1985) The Biology of Cell Proliferation. Cambridge, MA: H arvard U niversity Press.

Coppola D, Ferber A, Miura M et al. (1994) A functional insulin-like growth factor I receptor is required for the mitogenic and transforming activities of the epidermal growth factor receptor. $\mathrm{Mol}$. Cell. Biol. 14, 4588.

DeAngelis T, Ferber A, Baserga R. (1995) Insulin-like growth factor I receptor is required for the mitogenic and transforming activities of the platelet-derived growth factor receptor. J. Cell. Physiol. $164,214$.

Dulak NC, TEM IN HM. (1973a) A partially purified polypeptide fraction from rat liver cell conditioned medium with multiplication-stimulating activity for embryo fibroblasts. J. Cell. Physiol. 81, 153.

DuLAK NC, TEM IN HM. (1973b) Multiplication-stimulating activity for chicken embryo fibroblasts from rat liver cell conditioned medium: a family of small polypeptides. J. Cell. Physiol. 81, 161.

DULAK NC, SHING YW. (1977) Lrge scale purification and further characterization of a rat liver cell conditioned medium multiplication stimulating activity. J. Cell. Physiol. 90, 127.

HAYFLICK L. (1965) The limited in vitro lifetime of human diploid cell strains. Exp. Cell Res. 37, 614.

LiU JP, BAKER J, Perkins AS et al. (1993) Mice carrying null mutations of the genes encoding insulinlike growth factor I (Igf-1) and type-1 IGF receptor (Igf1r). Cell 75, 59.

Miura M, Surmacz E, Burgaud Jl, Baserga R. (1995) Different effects on mitogenesis and transformation of a mutation at tyrosine 1251 of the insulin-like growth factor I receptor. J. Biol. Chem. 270, 22639.

Morrione A, DeAngelis T, Baserga R. (1995) Failure of the bovine papillomavirus to transform mouse embryo fibroblasts with a targeted disruption of the insulin-like growth factor I receptor genes. J. Virol. 69, 5300.

Morrione A, Valentinis B, Xu SQ et al. (1997) Insulin-like growth factor II stimulates cell proliferation through the insulin receptor. Proc. Natl. Acad. Sci. USA 94, 3777.

Nissley SP, Short PA, Rechler MM et al. (1977) Proliferation of buffalo rat liver cells in serum-free medium does not depend upon multiplication-stimulating activity (MSA). Cell 11, 441.

Rubini M, Hongo A, D'Ambrosio C, Baserga R. (1997) The IGF-I receptor in mitogenesis and transformation of mouse embryo cells: role of receptor number. Exp. Cell Res. 230, 284.

Sell C, Rubini M, Rubin R et al. (1993) Simian virus 40 large tumor antigen is unable to transform mouse embryonic fibroblasts lacking type-1 Insulin-like growth factor receptor. Proc. Nal. Acad. Sci. USA 90, 11217. 
Sell C, Dumenil G, Deveaud C et al. (1994) Effect of a null mutation of the insulin-like growth factor I receptor gene on growth and transformation of mouse embryo fibroblasts. Mol. Cell. Biol. 14, 3604.

Soule HD, Vazguez J, Long A et al. (1973) A human cell line from a pleural effusion derived from a breast carcinoma. J. Natl. Cancer Inst. 51, 1409.

SRivastava SK, Y uASA Y, Reynolds SH, Aaronson SA. (1985) Effects of two major activating lesions on the structure and conformation of human ras oncogene products. Proc. Natl. Acad. Sci. USA 82, 38.

StE IN GH . (1979) T98G : an anchorage-independent human tumor cell line that exhibits stationary phase G 1 arrest in vitro. J. Cell. Physiol. 99, 43.

Steller MA, Zou Z, Schiller JT, Baserga R . (1996) Transformation by human papillomavirus 16 E 6 and $E$ 7: role of the insulin-like growth factor 1 receptor. Cancer Res. 56, 5087.

Straus DS, Coppock DL, PANG KJ. (1981) Low molecular weight mitogenic factor produced by BRL-3A cultured rat liver cells. Biochem. Biophys. Res. Commun. 100, 1619.

Valentinis B, Porcu P, Quinn K, Baserga R. (1994) The role of the insulin-like growth factor I receptor in the transformation by simian virus $40 \mathrm{~T}$ antigen. Oncogene $\mathbf{9}, 825$.

Valentinis B, Morrione A, Taylor SJ, Baserga R. (1997) Insulin-like growth factor I receptor signaling in transformation by src oncogenes. Mol. Cell. Biol. 17, 3744. 